\title{
Salinity and nitrogen doses in the production and oil content of castor bean
}

\section{Salinidade e doses de nitrogênio na produção e teor de óleo da mamoneira}

\author{
Allan Nunes Alves ${ }^{1 *}$; Hans Raj Gheyi²; José Amilton Santos Junior ${ }^{3}$; \\ Fernando José da Silva Junior ${ }^{4}$; Frederico Antônio Loureiro Soares ${ }^{5}$; \\ Cláudio Augusto Uyeda ${ }^{6}$
}

\begin{abstract}
The proper management of irrigation and mineral nutrition is critical to the success of crops, especially crops grown under salt stress conditions. The objective of this study was to evaluate the production and oil content of castor plants (Ricinus communis L.) irrigated with brackish water with different salinity levels $\left(0.6,1.6,2.6,3.6\right.$, and $\left.4.6 \mathrm{dS} \mathrm{m}^{-1}\right)$ and grown under different nitrogen levels $(50,75,100,125$, and $150 \mathrm{mg}$ of $\mathrm{N} \mathrm{kg}^{-1}$ soil). These treatments were arranged in a completely randomized block design with a $5 \times 5$ factorial scheme and three repetitions, totaling 75 experimental units. The interaction effect between salinity levels and nitrogen levels affected fruit weight per plant and oil content, and irrigation with brackish water with an electrical conductivity starting at $0.6 \mathrm{dS} \mathrm{m}^{-1}$ reduced the number of racemes per plant, number of fruits, and the weight of fruits and seeds.
\end{abstract}

Key words: Irrigation. Brackish waters. Ricinus communis.

\section{Resumo}

O manejo adequado da irrigação e da nutrição mineral é fundamental para o êxito de cultivos, ainda mais, sob condições de estresse salino. Neste viés, o objetivo do presente estudo foi avaliar a produção e teor de óleo da mamoneira (Ricinus communis L.) irrigada com águas salobras $(0,6 ; 1,6 ; 2,6 ; 3,6$ e 4,6 $\left.\mathrm{dS} \mathrm{m}^{-1}\right)$ sob aplicação de doses de adubação nitrogenada a base de ureia $(50,75,100,125$ e $150 \mathrm{mg}$ de $\mathrm{N} \mathrm{kg}^{-1}$ de solo). Estes tratamentos foram distribuídos em blocos inteiramente casualizados, analisados em esquema fatorial $5 \times 5$, com três repetições, totalizando 75 unidades experimentais. A interação salinidade vs nitrogênio influenciou o comportamento do peso dos frutos por planta assim como o seu teor de óleo, e a aplicação de água salobra via irrigação com condutividade elétrica a partir de $0,6 \mathrm{dS} \mathrm{m}^{-1}$ provocou reduções no número de racemos e frutos por planta, peso dos frutos e de sementes.

Palavras-chave: Irrigação. Águas salobras. Ricinus communis

1 Dr. em Engenharia Agrícola, Universidade Federal de Campina Grande, UFCG, Campina Grande, PB, Brasil. E-mail: allan_1nunes@yahoo.com.br

2 Prof., Departamento de Engenharia Agrícola, UFCG, Campina Grande, PB, Brasil. E-mail: hans@agriambi.com.br

3 Prof., Departamento de Engenharia Agrícola, Universidade Federal Rural de Pernambuco, UFRPE, Recife, PE, Brasil. E-mail: eng.amiltonjr@hotmail.com

4 Me. em Engenharia Agrícola, UFRPE, Recife, PE, Brasil. E-mail: nando_fj18@hotmail.com

5 Prof., Instituto Federal Goiano, IFGO, Rio Verde, GO, Brasil. E-mail: fredalsoares@hotmail.com

6 Prof., Instituto Federal de Pernambuco, IFPE, Vitória de Santo Antão, PE, Brasil. E-mail: claudio.uyeda@vitoria.ifpe.edu.br

* Author for correspondence 


\section{Introduction}

The increase in agricultural production has required more water for irrigation and, in conditions of limited water resources for irrigation, the trend has been the use of alternative quality water such as brackish water, which is abundant in the semiarid regions of Brazil (NOBRE et al., 2011).

However, the use of brackish water in irrigation requires adopting practices that mitigate its deleterious effect on the soil and crops, including the choice of tolerant plant species and cultivars, water mixing, use of water sources with different salinity levels, and the management of nitrogen fertilization. The latter is one of the main techniques used to increase crop productivity under salt stress conditions (MARINHO et al., 2010).

Nitrogen fertilization can promote plant growth and reduce the effect of salt stress on plants (BARHOUMI et al., 2010). In this respect, the nitrate to chloride ratio in plants may be an essential indicator of their tolerance to salinity, and high levels of chloride and nitrate lead to disorders due to the antagonistic effect between these ions (GREENWAY; MUNNS, 1980).

The effects of nitrogen on plant metabolism, including the formation of proteins, amino acids, and nucleic acids, are even more significant under salt stress conditions and include better osmotic adjustment and higher oil production (BARHOUMI et al., 2010; MARINHO et al., 2010). Although mineral nutrition is crucial for plant development, and nitrogen is the macronutrient most required by agricultural crops (MILLER; CRAMER, 2004), cultivation under salt stress requires the use of a combination of cultivation techniques, including nitrogen fertilization, to maximize crop yield (MARINHO et al., 2010).

Castor plants (Ricinus communis L.) from the family Euphorbiaceae stands out because of their high agroindustrial potential and tolerance to environmental stresses such as drought, presence of heavy metals, and salt stress (BABITA et al., 2010). These characteristics allow their cultivation in the semiarid regions of Brazil, and this activity creates jobs and generates income for family farmers living in this region (NOBRE et al., 2012). Castor oil has been used as a raw material for biofuel production because of its long shelf life, high solubility, and production cost-effectiveness (ENCINAR et al., 2012).

The objective of this study is to evaluate the production and oil content of castor plants irrigated with water with different sodium chloride concentrations and grown under different nitrogen levels.

\section{Materials and Methods}

The study was conducted in a greenhouse of the Graduate Program in Agricultural Engineering of the Federal University of Campina Grande $\left(7^{\circ} 15^{\prime} 18^{\prime \prime} \mathrm{S}, 35^{\circ} 52^{\prime} 28^{\prime}\right.$ ' W, mean altitude of $\left.550 \mathrm{~m}\right)$ under mean climatic conditions, with temperatures ranging from the maximum annual average of 28.6 ${ }^{\circ} \mathrm{C}$ and the minimum of $19.5{ }^{\circ} \mathrm{C}$, mean relative humidity of $80 \%$, and average solar radiation of 18 $\mathrm{MJ} / \mathrm{m}^{2}$ day $^{-1}$.

The treatments consisted of irrigation water with different electrical conductivity (EC) $(0.6,1.6,2.6$, 3.6 , and $4.6 \mathrm{dS} \mathrm{m}^{-1}$ ) for growing castor plants (cv. BRS Energia) under different nitrogen levels (50, $75,100,125$, and $150 \mathrm{mg} \mathrm{kg}^{-1}$ soil). These treatments were arranged in a completely randomized block design using a $5 \times 5$ factorial scheme and three repetitions.

The experimental plots consisted of drainage lysimeters constructed with $100-\mathrm{L}$ plastic pots with two holes in the bottom and connected to plastic containers by a tube to collect the drained volume. Each pot was filled with a layer of coarse gravel (1 $\mathrm{kg})$ and a layer of soil $(120 \mathrm{~kg})$ with a nylon mesh between the two layers. The pots were filled up to a height of $5 \mathrm{~cm}$ from the upper edge. 
The soil used was collected in the São José da Mata district, Campina Grande, state of Paraíba, Brazil (7'04'11.0" S 36 $06^{\circ} 24.8^{\prime \prime} \mathrm{S}$ ) in the $0-30$ $\mathrm{cm}$ deph and was classified (EMBRAPA, 2006) as eutrophic Regolithic Neosol. The soil presented the following composition according to Claessen (1997): sand (734 $\left.\mathrm{g} \mathrm{kg}^{-1}\right)$, silt $\left(168 \mathrm{~g} \mathrm{~kg}^{-1}\right)$, clay (98 g $\left.\mathrm{kg}^{-1}\right)$, density $\left(1.42 \mathrm{~kg} \mathrm{dm}^{-3}\right)$, and porosity (49.47\%). The following exchangeable ions were present in the soil: $\mathrm{Ca}, 11.9 \mathrm{mmol}_{\mathrm{c}} \mathrm{kg}^{-1} ; \mathrm{Mg}, 11.9 \mathrm{mmol}_{\mathrm{c}} \mathrm{kg}^{-1}$, $\mathrm{Na}, 5.6 \mathrm{mmol}_{\mathrm{c}} \mathrm{kg}^{-1} ; \mathrm{K}, 0.6 \mathrm{mmol}_{\mathrm{c}} \mathrm{kg}^{-1} ; \mathrm{pH}$ of the saturation extract, 5.22; EC of the saturation extract, $0.52 \mathrm{dS} \mathrm{m}^{-1} ; \mathrm{Ca}^{2+}, 2.75 \mathrm{mmol}_{\mathrm{c}} \mathrm{L}^{-1} ; \mathrm{Mg}^{2+}, 2.13 \mathrm{mmol}_{\mathrm{c}}$ $\mathrm{L}^{-1} ; \mathrm{Na}^{+}, 1.54 \mathrm{mmol}_{\mathrm{c}} \mathrm{L}^{-1} ; \mathrm{K}^{+}, 0.53 \mathrm{mmol}_{\mathrm{c}} \mathrm{L}^{-1} ; \mathrm{Cl}^{-}$ $5.00 \mathrm{mmol}_{\mathrm{c}} \mathrm{L}^{-1} ; \mathrm{CO}_{3}{ }^{2-}, 0 \mathrm{mmol}_{\mathrm{c}} \mathrm{L}^{-1} ; \mathrm{HCO}^{-}, 1.60$ $\mathrm{mmol}_{\mathrm{c}} \mathrm{L}^{-1}$; saturation percentage, $20.0 \%$. The soil was non-saline and non-sodic, and soil texture was sandy loam.

With respect to mineral fertilization, at the time of pot filling, $300 \mathrm{mg}$ of $\mathrm{P}_{2} \mathrm{O}_{5}(100 \%$ of respective dose), $50 \mathrm{mg}$ of $\mathrm{K}_{2} \mathrm{O}$ (1/3 of the total recommendation), and urea ( $1 / 3$ of the recommendation) were used for each $\mathrm{kg}$ of soil. In topdressing fertilization, the remaining nitrogen and potassium $(2 / 3$ of the recommendation) were distributed in five equal applications at 20,30, 40, 50, and 60 days after sowing (DAS) to avoid salt accumulation.

Water sources were prepared by dissolving sodium chloride in the municipal supply water (Richards, 1954). Irrigation was performed daily, and the calculation of the irrigation volume was based on the soil water balance, as follows: water volume used in the previous irrigation minus the drained volume plus a leaching fraction of $10 \%$ to prevent salt buildup in the soil. Irrigation was performed manually.

Sowing was carried out at field capacity, and six seeds were distributed equidistantly in each pot at a depth of $2 \mathrm{~cm}$. Thinning of the less vigorous plants was performed at 20,30, and $42 \mathrm{DAS}$, leaving one plant per pot. Throughout the crop cycle, no hydroclimatological changes or phytosanitary problems compromised plant development. The weeds were removed weekly by hand.

The following variables were analyzed at the end of the crop cycle (120 DAS): number of racemes per plant (NRP), number of fruits in the main raceme (NFMR), number of fruits per plant (NFP), weight of fruits in the main raceme (WFMR), weight of fruits per plant (WFP), number of seeds in the main raceme (NSMR), number of seeds per plant (NSP), weight of seeds in the main raceme (WSMR), and weight of seeds per plant (WSP). Seed oil content (OC) was determined as recommended by the AOCS (2000).

After performing the normality test, the data were subjected to analysis of variance using the F-test at a level of significance of $5 \%$ and $1 \%$. In cases of significance of the interaction effect between salinity levels and nitrogen doses, the effect was analyzed and, in the other cases, the isolated effects were compared by polynomial regression analysis using statistical software (FERREIRA, 2011).

\section{Results and Discussion}

NRP, NFMR, NFP, WFMR, and WFP were strongly affected by the salinity level of the irrigation water, whereas nitrogen fertilization influenced WFMR and WFP. There was a significant interaction effect between salinity and nitrogen doses on WFP (Table 1).

There was a 1.56 unit decrease in the NRP per unit increase in the EC of irrigation water (Figure 1A). Nobre et al. (2012) observed that the NRP decreased by $14.2 \%$ per unit increase in EC in the same castor plant cultivar used in the present study. In both cases, irrigation water salinity affected the NRP, probably because of changes in the absorption and utilization of essential nutrients (AMORIM et al., 2010). 
Table 1. Analysis of variance for the number of racemes per plant (NRP), number of fruits in the main raceme (NFMR), number of fruits per plant (NFP), weight of fruits in the main raceme (WFMR), and weight of fruits per plant (WFP) in castor plants irrigated with brackish water and fertilized with different nitrogen doses.

\begin{tabular}{lcccccc}
\hline \multirow{2}{*}{ Sources of Variation } & \multicolumn{5}{c}{ Medium square } \\
\cline { 2 - 6 } & GL & NRP $^{1}$ & NFMR $^{1}$ & NFP $^{1}$ & WFMR $^{1}$ & WFP \\
\hline Salinity Levels (SL) & 4 & $4.03^{* *}$ & $53.28^{* *}$ & $180.22^{* *}$ & $87.41^{* *}$ & $136234.54^{* *}$ \\
Linear Regression & & $14.83^{* *}$ & $205.81^{* *}$ & $719.85^{* *}$ & $339.22^{* *}$ & $535915.75^{* *}$ \\
Quadratic Regression & & $0.66^{\text {ns }}$ & $2.87^{\text {ns }}$ & $0.16^{\text {ns }}$ & $8.73^{* *}$ & $7023.86^{* *}$ \\
Nitrogen Doses (ND) & 4 & $0.07^{\text {ns }}$ & $1.28^{\text {ns }}$ & $3.36^{\text {ns }}$ & $0.36^{\text {ns }}$ & $1989.44^{*}$ \\
Linear Regression & & $1.13^{\text {ns }}$ & $4.19^{\text {ns }}$ & $12.98^{\text {ns }}$ & $0.44^{\text {ns }}$ & $5741.23^{* *}$ \\
Quadratic Regression & & $0.23^{\text {ns }}$ & $0.55^{\text {ns }}$ & $0.43^{\text {ns }}$ & $0.48^{\text {ns }}$ & $215.64^{\text {ns }}$ \\
Interaction SL x ND & 16 & $0.11^{\text {ns }}$ & $1.18^{\text {ns }}$ & $2.17^{\text {ns }}$ & $1.42^{\text {ns }}$ & $1382.22^{* *}$ \\
Blocks & 2 & $0.16^{\text {ns }}$ & $0.16^{\text {ns }}$ & $0.16^{\text {ns }}$ & $0.5^{\text {ns }}$ & $568.92^{\text {ns }}$ \\
Residue & 48 & 0.18 & 1.19 & 1.72 & 1.16 & 540.24 \\
CV $(\%)$ & & 17.79 & 13.12 & 11.37 & 12.34 & 15.65 \\
\hline
\end{tabular}

** and * significant at 0.01 and 0.05 probability; ${ }^{\text {ns }}$ not significant by test $\mathrm{F}$. ${ }^{1}$ Data transformed by $\sqrt{x}_{\mathrm{X}}$.

Figure 1. (A) Number of racemes per plant, (B) number of fruits in the main raceme and number of fruits per plant, (C) weight of fruits in the main raceme. Analysis of the interaction effect between (D) water salinity levels and (E) nitrogen doses on fruit weight in castor plants.

A.

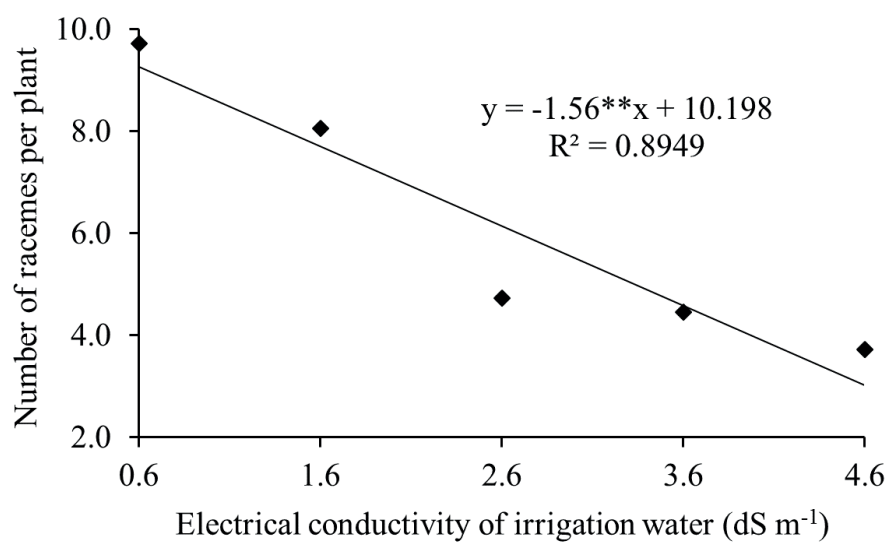

B.

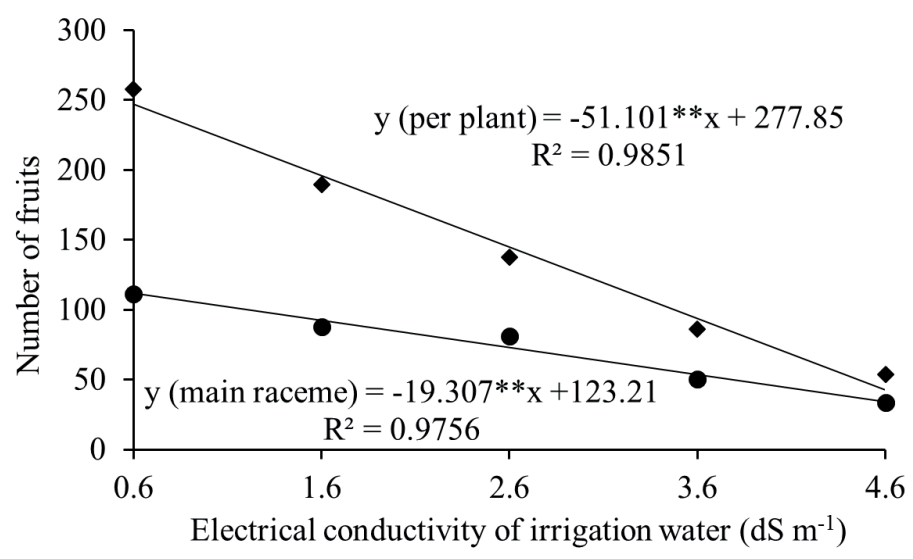


C.

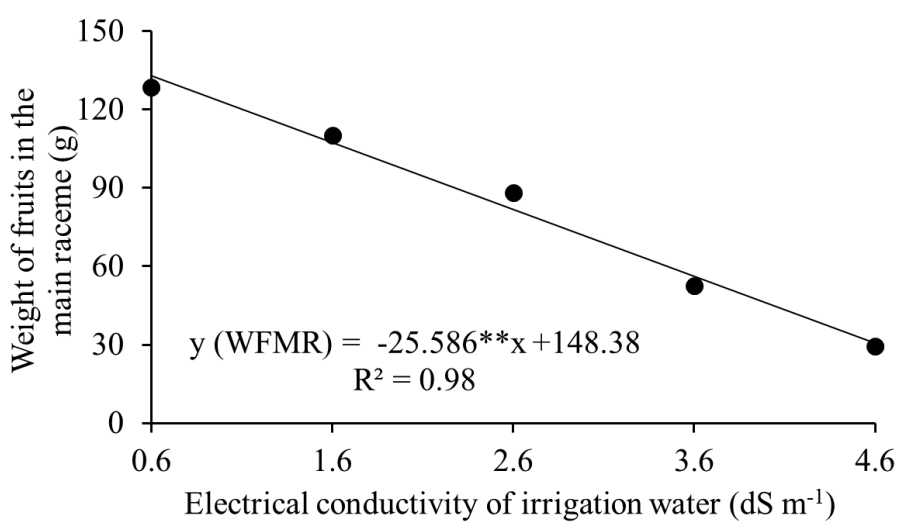

D.

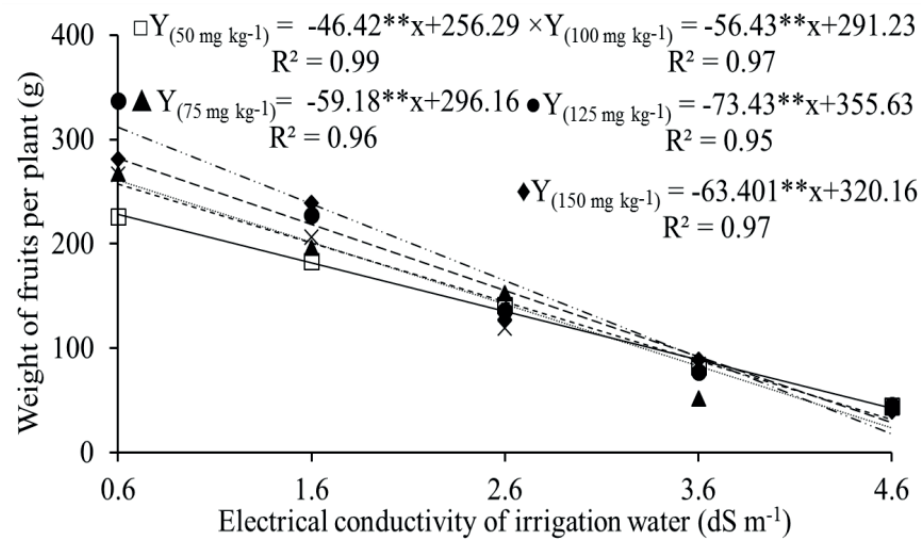

E.

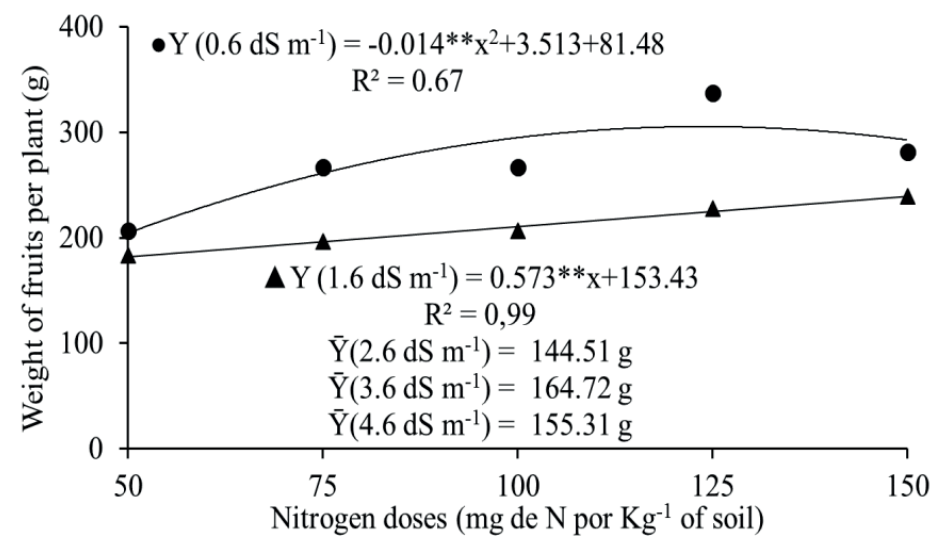

There was a linear decreasing trend in the NFMR (19.3 units per unit increase in EC) and NFP (51.1 units per unit increase in EC) as irrigation water salinity increased. Santos et al. (2012) have shown that this tendency is because the plants adjust osmotically by using energy to store sugars, organic acids, and ions in the vacuoles, consequently reducing the amount of energy available for plant growth and production.
The estimated decrease in WFMR was 25.58 $\mathrm{g}$ per unit increase in EC in irrigation water, and WFMR in plants irrigated with water of EC of $4.6 \mathrm{dS}$ $\mathrm{m}^{-1}$ decreased by $76.9 \%$ relative to control cultivated with $0.6 \mathrm{dS} \mathrm{m}^{-1}$ (Figure 1C). Nevertheless, Silva et al. (2008) analyzed two castor plant cultivars (BRS Paraguaçu and BRS Energia) irrigated with brackish water with different salt levels $(0.7,2.7$, 4.7, and $6.7 \mathrm{dS} \mathrm{m}^{-1}$ ) and concluded that WFMR at 
$4.7 \mathrm{dS} \mathrm{m}^{-1}$ was $96.7 \%$ lower than that at $0.7 \mathrm{dS} \mathrm{m}^{-1}$, and the reduction was statistically similar between the cultivars.

The analysis of the interaction effect between treatments indicated that the unit increase in EC in irrigation water decreased WFP by 18.1, 20.0, 19.4, 20.6, and $19.8 \%$ in plants fertilized with 50, 75, 100,125 , and $150 \mathrm{mg}$ of $\mathrm{N} \mathrm{kg}^{-1}$, respectively (Figure 1D). The analysis of nitrogen fertilization indicated that salinity decreased WFP in plants irrigated with water with an EC between 0.6 and $1.6 \mathrm{dSm}^{-1}$ (Figure 1E). In the first case, WFP was highest (301.9 g) at a nitrogen dose of $125.5 \mathrm{mg} \mathrm{kg}^{-1}$ and decreased to $293.5 \mathrm{~g}$ at a dose of $150 \mathrm{mg} \mathrm{kg}^{-1}$. In the second case, WFP increased linearly by $31.4 \%$ from a nitrogen dose of $50 \mathrm{mg} \mathrm{kg}^{-1}$ to $150 \mathrm{mg} \mathrm{kg}^{-1}$ of soil.
The increase in fruit weight in plants irrigated with water with an EC between 0.6 and $1.6 \mathrm{dS} \mathrm{m}^{-1}$ may be related to the salt concentration in the root zone and indicates that when ECa is within the set limits, the plant responds more consistently to nitrogen fertilization with significantly increasing yield.

Irrigation water salinity had a significant effect on NSMR, NSP, WSMR, WSP, and OC. Nitrogen fertilization did not significantly affect these variables; nonetheless, the interaction effect between salinity levels and nitrogen doses strongly affected OC (Table 2).

Table 2. Summary of the analysis of variance for the number of seeds in the main raceme (NSMR), number of seeds per plant (NSP), weight of seeds in the main raceme (WSMR), weight of seeds per plant (WSP), and oil content (OC) in castor plants under different salinity levels and nitrogen doses.

\begin{tabular}{|c|c|c|c|c|c|c|}
\hline \multirow{2}{*}{ Sources of Variation } & \multirow{2}{*}{ GL } & \multicolumn{5}{|c|}{ Quadrados médio } \\
\hline & & NSMR $^{1}$ & $\mathrm{NSP}^{1}$ & WSMR $^{1}$ & WSP & $\mathrm{OC}$ \\
\hline Salinity Levels (SL) & 4 & $152.56^{* *}$ & $525.29^{* *}$ & $64.52^{* *}$ & $63335.14^{* *}$ & $27.80^{* *}$ \\
\hline Linear Regression & & $593.83^{* *}$ & $2094.28^{* *}$ & $250.01^{* *}$ & $248408.38^{* *}$ & $70.81^{* *}$ \\
\hline Quadratic Regression & & $10.32^{\text {ns }}$ & $0.56^{\mathrm{ns}}$ & $7.28^{*}$ & $3569.57^{* *}$ & $9.64^{\mathrm{ns}}$ \\
\hline Nitrogen Doses (ND) & 4 & $1.32^{\mathrm{ns}}$ & $5.96^{\mathrm{ns}}$ & $8.56^{\mathrm{ns}}$ & $598.53^{\mathrm{ns}}$ & $6.56^{\mathrm{ns}}$ \\
\hline Interaction SL x ND & 16 & $2.41^{\mathrm{ns}}$ & $5.12^{\mathrm{ns}}$ & $5.04^{\mathrm{ns}}$ & $443.58^{\mathrm{ns}}$ & $14.08^{*}$ \\
\hline Blocks & 2 & $0.22^{\mathrm{ns}}$ & $2.11^{\mathrm{ns}}$ & $2.67^{\mathrm{ns}}$ & $372.77^{\mathrm{ns}}$ & $0.72^{\mathrm{ns}}$ \\
\hline Residue & 48 & 3.36 & 4.43 & 4.48 & $349.76^{\mathrm{ns}}$ & 6.49 \\
\hline CV (\%) & & 13.56 & 11.41 & 18.51 & 19.88 & 4.80 \\
\hline
\end{tabular}

${ }^{* *}$ and ${ }^{*}$ significant at 0.01 and 0.05 probability; ${ }^{\text {ns }}$ not significant by test $\mathrm{F}$. ${ }^{1}$ Data transformed by $\sqrt{ } \mathrm{x}$.

In plants irrigated with water of EC of $0.6 \mathrm{dS}$ $\mathrm{m}^{-1}$, NSMR was estimated at 350.38 units and decreased by $24.4,48.8,73.3$, and $97.7 \%$ in plants cultivated with an EC of 1.6, 2.6, 3.6, and $4.6 \mathrm{dS}$ $\mathrm{m}^{-1}$, respectively (Figure 2A). Lima et al. (2015) observed that NSMR decreased 33.39 units per unit increase in EC in castor plants of the same cultivar irrigated with an EC between 0.3 and $3.9 \mathrm{dS} \mathrm{m}^{-1}$, and attributed these results to the toxic effects of salts absorbed by plants, especially $\mathrm{Na}^{+}$and $\mathrm{Cl}^{-}$, the low osmotic adjustment capacity of the crop, and the reduction in total water potential caused by the increase in salinity. NSP decreased linearly by $85.2 \%$ as EC increased from 0.6 to $4.6 \mathrm{dS} \mathrm{m}^{-1}$, corresponding to a reduction of 553.8 seeds per plant (Figure 2A). 
Figure 2. (A) Number of seeds in the main raceme and number of seeds per plant; (B) weight of seeds in the main raceme and weight of seeds per plant. Analysis of the interaction effect between (D) water salinity levels and (E) nitrogen doses on oil content.

A.

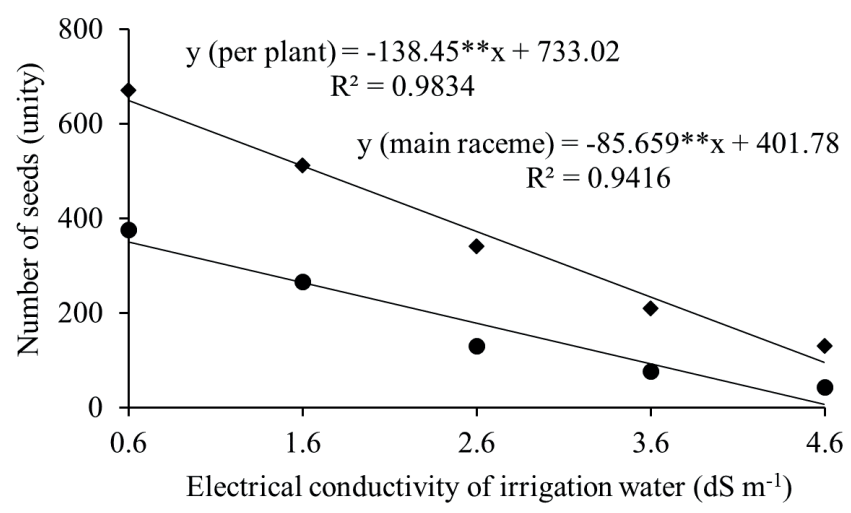

B.

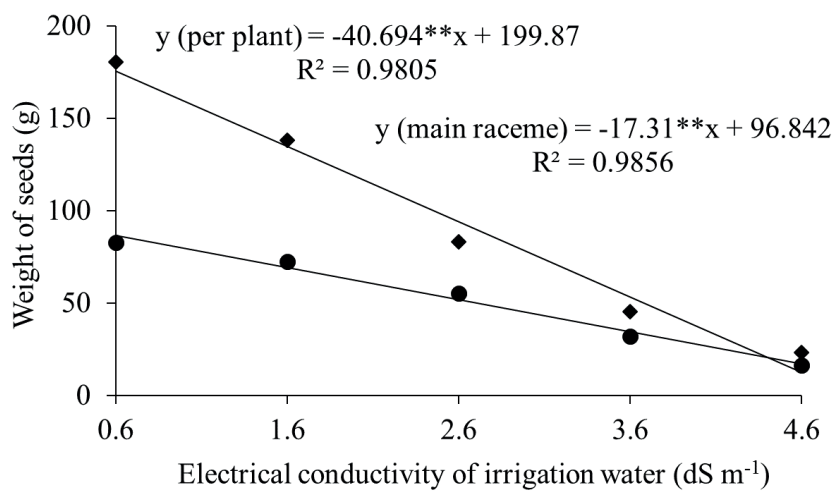

C.

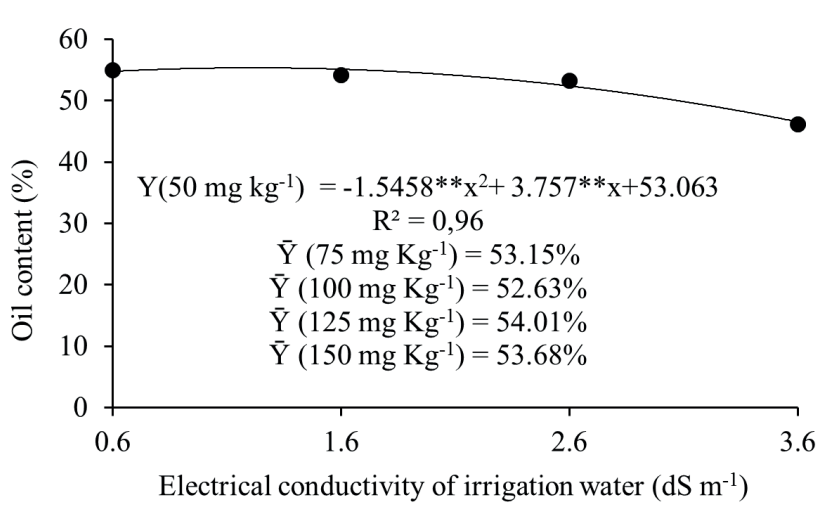

D.

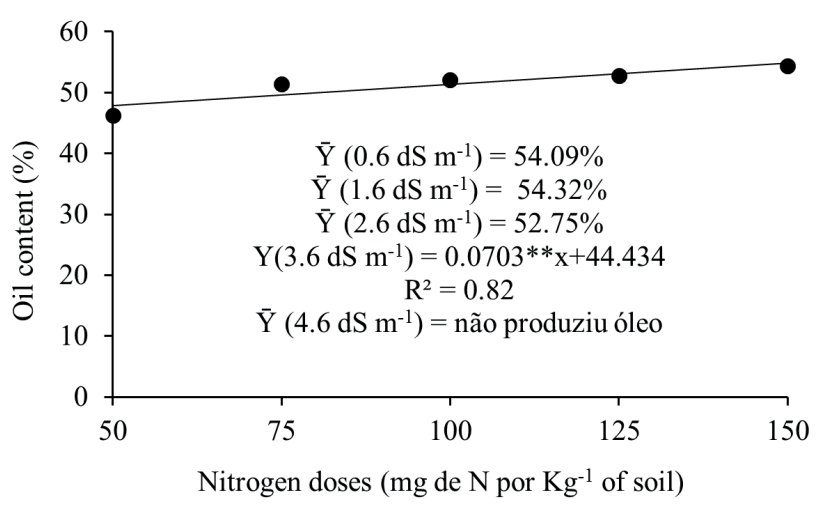


WSMR decreased by $20,40,60$, and $80 \%$ using irrigation water with an EC of 1.6, 2.6, 3.6, and 4.6 $\mathrm{dS} \mathrm{m}{ }^{-1}$, respectively, relative to an EC of $0.6 \mathrm{dS} \mathrm{m}^{-1}$ (Figure 2B). Similarly, Silva et al. (2008) evaluated the development and production of two castor plant cultivars (BRS Paraguaçu and BRS Energia) under salt stress and found that seed weight in plants maintained at an EC of $4.7 \mathrm{dS} \mathrm{m}^{-1}$ was $96.8 \%$ lower than that of plants cultivated with $0.7 \mathrm{dS} \mathrm{m}^{-1}$ water, and this reduction was attributed to the sensitivity of castor plants to irrigation water salinity.

WSP was also affected by EC and decreased by $92.77 \%$ as EC increased from 0.6 to $4.6 \mathrm{dS} \mathrm{m}^{-1}$, corresponding to a reduction of $162.7 \mathrm{~g}$ (Figure $2 \mathrm{~B}$ ). These results corroborate those found by Lima et al. (2014), in which WSP decreased by $72.7 \%$ in castor plants cv. BRS Energia as the EC of irrigation water increased from 0.4 to $4.4 \mathrm{dS} \mathrm{m}^{-1}$.

OC was maximum (55.34\%) in plants fertilized with $50 \mathrm{mg}$ of $\mathrm{N} \mathrm{kg}^{-1}$ of soil at an EC of $1.21 \mathrm{ds}$ $\mathrm{m}^{-1}$ (Figure $2 \mathrm{C}$ ). OC was higher than $52 \%$ in plants irrigated with brackish water at the analyzed EC range using nitrogen doses higher than $75 \mathrm{mg} \mathrm{kg}^{-1}$ of soil. Nonetheless, OC was not detected in plants maintained at $4.6 \mathrm{dS} \mathrm{m}^{-1}$. Nobre et al. (2012) found that OC decreased up to $27.9 \%$ in castor plants $\mathrm{cv}$. BRS Energia irrigated with water of EC of $4.4 \mathrm{dS} \mathrm{m}^{-1}$ and concluded that the increase in EC decreased OC linearly by $2.5 \%$ and $7.0 \%$ in primary and secondary racemes, respectively, in plants maintained at $4.4 \mathrm{dS}$ $\mathrm{m}^{-1}$ relative to those maintained at $0.4 \mathrm{dS} \mathrm{m}^{-1}$.

The increase in nitrogen dose from 50 to $150 \mathrm{mg}$ $\mathrm{kg}^{-1}$ increased OC by $14.66 \%$ in plants irrigated with brackish water of EC $3.6 \mathrm{dS} \mathrm{m}^{-1}$ (Figure 2D). The increase in nitrogen doses did not significantly affect $\mathrm{OC}$ in plants irrigated with water of EC 0.6, 1.6, and $2.6 \mathrm{dS} \mathrm{m}^{-1}$, which remained above $52 \%$. However, $\mathrm{OC}$ was not detected in plants irrigated with water at $4.6 \mathrm{dS} \mathrm{m}^{-1}$. In contrast, Nobre et al. (2012) observed that a $25 \%$ increase in the recommended nitrogen dose caused an average decrease of $3.6 \%$ and $3.5 \%$ in the OC of seeds in the primary and secondary raceme, respectively, in castor plants cv. BRS Energia irrigated with brackish water.

Duarte et al. (2005) and Silva et al. (2007) found that $\mathrm{OC}$ was not affected as nitrogen fertilization increased. Severino et al. (2006) reported that OC in commercial castor plant cultivars was $48 \%$, whereas the OC obtained in the present study was higher than $52 \%$.

\section{Conclusions}

1. The interaction effect between salinity levels and nitrogen doses affected the weight of fruits per plant and the oil content of caster seeds.

2. The use of brackish water in irrigation reduced the number of racemes per plant, number of fruits, weight of fruits, and weight of seeds of castor plants cv. BRS Energia.

3. Nitrogen fertilization of castor plants cv. BRS Energia irrigated with saline water affected total fruit weight per plant.

\section{References}

AMERICAN OIL CHEMISTS' SOCIETY - AOCS. Official methods and recommended practices of the. 5 . ed. Champaign: AOCS, 2000.

AMORIM, A. V.; GOMES-FILHO, E.; BEZERRA, M. A.; PRISCO, J. T.; LACERDA, C. F. Respostas fisiológicas de plantas adultas de cajueiro anão precoce à salinidade. Revista Ciência Agronômica, Fortaleza, v. 41, n. 1 , p. $113-121,2010$. DOI:10.5935/18066690.20100016

BABITA, A, M.; MAHESWARIB, M.; RAOA, L. M.; SHANKERB, A. K.; GANGADHAR R. D. Osmotic adjustment, drought tolerance and yield in castor (Ricinus communis L.) hybrids. Journal Environmental and Experimental Botany, Oxford, v. 69, n. 3, p. 243-249, 2010. DOI: $10.1016 /$ j.envexpbot.2010.05.006

BARHOUMI, Z.; ATIA, A.; RABHI, M.; DJEBALL, W.; ABDELLY, C.; SMAOUI, A. Nitrogen and $\mathrm{NaCl}$ salinity effects on the growth and nutrient acquisition of the grasses Aeluropus littoralis, Catapodium rigidum, and Brachypodium distachyum. Journal of Plant Nutrition 
and Soil Science, Londres, v. 173, n. 1, p. 149-157, 2010. DOI: $10.1002 / j p \ln .200800113$

CLAESSEN, M. E. C. (Org.). Manual de métodos de análise de solo. 2. ed. rev. atual. Rio de Janeiro: EMBRAPA-CNPS, 1997. 212 p. (Documentos, 1).

DUARTE, A. P.; MASON, S. C.; JACKSON, D. S.; KIEHL, J. C. Grain quality of Brazilian maize genotype as influenced by nitrogen level. Crop Science, Madison, v. 45, n. 1, p. 1958-1864, 2005. DOI: $10.2135 /$ cropsci2004.0587

EMPRESA BRASILEIRA DE PESQUISA AGROPECUÁRIA - EMBRAPA. Centro Nacional de Pesquisa de Solos. Sistema brasileiro de classificação de solos. 2. ed. Rio de Janeiro: Embrapa Solos, 2006.

ENCINAR, J. M.; GONZÁLEZ, J. F.; PARDAL, A. Transesterification of castor oil under ultrasonic irradiation conditions. Preliminary results. Fuel Processing Technology, Armsterdan, v. 103, n. 1, p. 9-15, 2012. DOI: $10.1016 /$ j.fuproc.2011.12.033

FERREIRA, D. F. Sisvar: computer statistical analysis system. Ciência \& Agrotecnologia, Lavras, v. 35 , n. 6 , p. $1039-1042$, 2011. DOI: $10.1590 / \mathrm{S} 1413-$ 70542011000600001

GREENWAY, H.; MUNNS, R. Mechanisms of salt tolerance in non-halophytes. Annual Review of Plant Physiology, Berkeley, v. 31, n. 1, 149-190, 1980. DOI: 10.1146/Annurev.pp.31.060180.001053

LIMA, G. S. D.; NOBRE, R. G.; GHEYI, H. R.; SOARES, L. A. D. A.; SILVA, A. O. D. Growth and components of production of castor bean under saline stress and nitrogen fertilization. Engenharia Agrícola, Jaboticabal, v. 34, n. 5, 854-866, 2014. DOI: 10.1590/ S0100-69162014000500005

LIMA, G. S.; NOBRE, R. G.; GHEYI, H. R.; SOARES, L. A. A.; SILVA, A. O. Produção da mamoneira cultivada com águas salinas e doses de nitrogênio. Revista Ciência Agronômica, Fortaleza, v. 46, n. 1, 1-10, 2015. DOI:10.1590/S1806-66902015000100001

MARINHO, A. B.; MOREIRA, L. G.; VIANA, T. V. A.; ALBUQUERQUE, A. H. P.; OLIVEIRA, C. W.; AZEVEDO, B. M. Influência da fertirrigação nitrogenada na produtividade da cultura da mamoneira. Revista Brasileira de Agricultura Irrigada, Fortaleza, v. 4, n. 1, p. 31-42, 2010. DOI: 10.7127/rbai.v4n100024
MILLER, A.J.; CRAMER, M. D. Root nitrogen acquisition and assimilation. Plant and Soil, Crawley, v. 274, n. 1, p. 1-36, 2004. DOI: 10.1007/s11104-004-09651

NOBRE, R. G.; GHEYI, H. R.; SOARES, F. A. L.; CARDOSO, J. A. F. Produção de girassol sob estresse salino e adubação nitrogenada. Revista Brasileira de Ciência do Solo, Viçosa, v. 35, n. 3, p. 929-937, 2011. DOI:10.1590/S0100-06832011000300027

NOBRE, R. G.; LIMA, G. S.; GHEYI, H. R.; MEDEIROS, E. P.; SOARES, L. A. A.; ALVES, A. N. Teor de óleo e produtividade da mamoneira de acordo com a adubação nitrogenada e irrigação com água salina. Pesquisa Agropecuária Brasileira, Brasília, v. 47, n. 7, p. 991-999, 2012. DOI: $10.1590 / \mathrm{S} 0100-204 X 2012000700016$

RICHARDS, L. A. Diagnosis and improvement of saline and alkali soils. Washington: U.S. Dept. of Agriculture, 1954. (Agricultural hand book 60.),

SANTOS, B.; FERREIRA, P. A.; OLIVEIRA, F. G. de; BATISTA, R. O.; COSTA, A. C.; CANO, M. A. O. Produção e parâmetros fisiológicos do amendoim em função do estresse salino. Revista Idesia, Arica, v. 30 , n. 2, p. 69-74, 2012. DOI:10.4067/S071834292012000200009

SEVERINO, L. S.; FERREIRA, G. B.; MORAES, C. R. A.; GONDIM, T. M. S.; CARDOSO, G. D.; VIRIATO, J. R.; BELTRÃO, N. E. M. Produtividade e crescimento da mamoneira em resposta à adubação orgânica e mineral. Pesquisa Agropecuária Brasileira, Brasília, v. 41 , n. 5 , p. $879-882,2006$. DOI: $10.1590 / \mathrm{S} 0100-$ 204X2006000500023

SILVA, S.; ALVES, A. N.; GHEYI, H. R.; BELTRÃO, N. E. D. M.; SEVERINO, L. S.; SOARES, F. A Desenvolvimento e produção de duas cultivares de mamoneira sob estresse salino. Revista Brasileira de Engenharia Agrícola e Ambiental, Campina Grande, v. 12 , n. 4 , p. $335-342,2008$. DOI: $10.1590 / \mathrm{S} 1415-$ 43662008000400001

SILVA, T. R. B.; LEITE, V. E.; SILVA, A. R. B.; VIANA, L. H. Adubação nitrogenada em cobertura na cultura da mamona em plantio direto. Pesquisa Agropecuária Brasileira, Brasília, v. 42, n. 9, p. 1357-1359, 2007. DOI:10.1590/S0100-204X2007000900018 
